\title{
Challenges for international and comparative law in the $\mathrm{UK}$
}

\author{
by Dame Mary Arden DBE
}

\begin{abstract}
Introducing this year's annual general meeting of the British Institute of International and Comparative Law on June 10, and the introductory lecture "2000-2005: laying the foundations of human rights law in the United Kingdom”, by Lord Steyn, Dame Mary made a number of observations in her opening address on the importance of research, policy discussion and scholarship in relation to international and comparative law issues.
\end{abstract}

$\mathrm{T}$ he last five years have seen many achievements and BIICL is now entering a phase of consolidation. The successful completion of the development appeal and the major government grant has provided a new financial basis for the Institute's work. But the margins remain thin, and fundraising and economising with the sparse resources of the Institute must continue. I would like to pay a personal tribute to Mads Andenas, the retiring Director of the Institute. We have much to thank Mads for. He is stepping down after more than five years, a period which has seen the Institute transformed, not least through his academic leadership and the development of an ambitious research programme. We wish Mads well in his new appointment as a professor of law at the University of Leicester. Professor Gillian Triggs of the University of Melbourne is taking over as the Director of the Institute from August 1, and we have high expectations of her. In spite of its history and achievements, the British Institute is an institution that can only succeed through reinvention and change.

Many challenges lie ahead. Recent, and no doubt future, legal developments underline the importance of a body such as BIICL. The breadth of its work, its inherent flexibility and independence distinguish it from other institutions. BIICL's work brings enormous benefit to the British legal community, both in the public and private sectors. A glance at the annual report will demonstrate the good work done, for instance, by the Company Law Centre in submitting response after response to the European Commission on proposed new European Union measures. There are many other examples in the annual report.

All major countries provide a more extensive infrastructure for international comparative law than we do in the United Kingdom. In Germany there are three
Max Planck Institutes in the field and there are a number of French and Italian university institutes. In all of these countries there is strong support from national research councils. Likewise in the US, there are different institutions which, with their access to private funding, also give a solid platform for policy discussion and scholarship. All these bodies offer their countries an advantage over the UK in many different contexts.

However, there is a problem, common to all countries. The well-established legal approaches, limited by a narrow definition of disciplines and by national traditions, do not meet the present needs. In comparative law the encyclopaedic collection and organisation of materials is still useful but not sufficient. The traditional teaching and scholarship in public international law and in the still relatively young disciplines of European law are equally inadequate. An additional problem here is the focus of one's own national approaches, for instance, to public international law and to EU law. These, while practically important, need to have a broader perspective. Fundamental assumptions about the nation state based on 19th century thinking still rule. But the way that international, European and domestic legal systems open up and recognise each other gives rise to fundamental questions that provide fertile ground for research and policy discussion.

This year BIICL has again had a lively year, with a packed events schedule, a plethora of research projects and an enviable publications output. BIICL has an impressive research record that includes areas as diverse as public authority liability, the organisation and procedure of international courts and tribunals, product liability, the law of treaties, state immunity in national and international law, comparative civil and criminal procedure, European 
constitutionalism and citizenship, corruption and development, e-commerce and EU and WTO law, global supply contracts, and competition law. There has also been a very important project on the death penalty in Africa, for which there is a session at the end of the day.

BIICL can only fulfil its functions by maintaining its high standard of academic excellence and independence. The relationship between the traditional disciplines of law is ever more in need of exploration. International law, European law and national legal orders are best understood as open systems co-existing without any clear hierarchy. But beyond that their relationship remains unresolved at the most fundamental levels. The relationship between disciplines with different legal orders or systems is of increasing importance, and distinctions, such as those between private and public law become difficult to maintain. There is a clear need to see this in context and to provide an international framework and support for academic research and deliver practice dealing with the many issues that arise.

There is an increasing need for an international European institutional basis for research and policy discussion. Some of this can be done through co-operation and networks involving existing institutions. BIICL has a key role to play here, and it is in the process of increasing its involvement in this form of co-operation where it has long and important traditions.

BIICL continued to expand its publishing programme in 2004, consolidating the achievement of the previous year and continuing its plan to become increasingly professional as an independent legal publisher. A wide variety of highquality books have been produced by the in-house publisher, masterminded by Orla Fee. Recent publications include the Competition Law Volume edited by Mads Andenas, Michael Hutchings and Philip Marsden, Independent Administrative Authorities, produced in collaboration with the University of Turin, and edited by Roberto Caranta, Mads Andenas and Duncan Fairgrieve, as well as a paperback version of the highly successful publication Comparative Law Before the Courts, edited by Premier President Guy Canivet, Mads Andenas and Duncan Fairgrieve.

The flagship of course is the International and Comparative Law Quarterly. Its general editors are Mads Andenas and Professor Alan Boyle. The ICLQ is an international journal. It also has a strong impact here in the UK, and three articles in the last 12 months or so illustrate this. Lord Bingham's article on wartime detention provided a historical perspective on wartime detention. This I am sure was a valuable reminder of the horrors of executive detention when the courts had to consider the Belmarsh case. Lord Hope's article "Torture" staked out the position on judicial treatment of torture. Lord Steyn's article on "Guantanamo Bay - a legal black hole", based on his F A Mann lecture organised by BIICL and Herbert Smith, made clear that English law would not allow a similar black hole. 도

Dame Mary Arden DBE

\title{
The 23rd Cambridge International Symposium on Economic Crime
} Sunday 4-Sunday 11 September 2005 Jesus College, Cambridge

\section{The Enterprise of Crime and Terror - The Implications for Good Business}

\author{
For further information contact Mrs Angela Futter, Symposium Manager, \\ Jesus College, Cambridge, CB5 8BL (tel: +44 (0) 1223 872160; \\ email: symposium@jesus.cam.ac.uk)
}

